
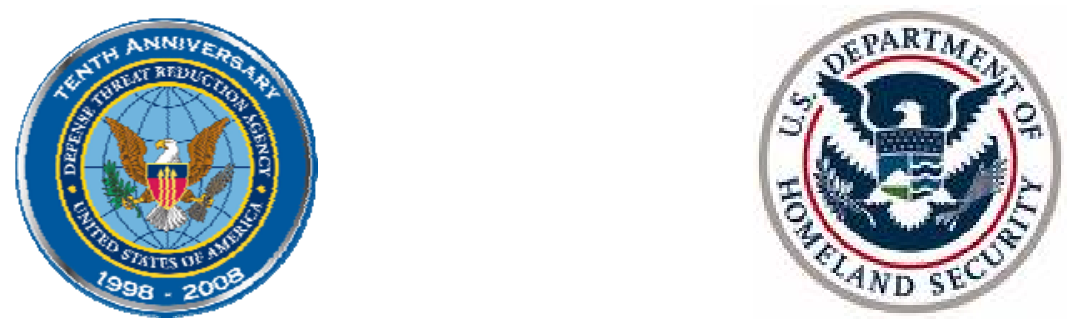

\title{
Economic Impacts of a Wide Area Release of Anthrax
}

May 2009

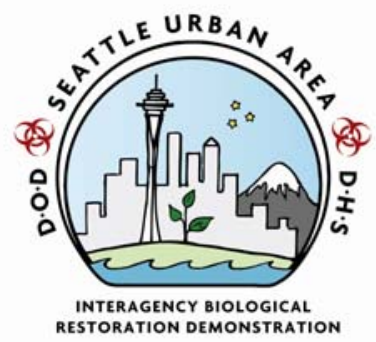

Prepared for the Interagency Biological Restoration Demonstration Program a program jointly funded by the Department of Defense, Defense Threat Reduction Agency and the Department of Homeland Security, Science \& Technology Directorate 
\{This page intentionally left blank\} 


\section{Economic Impacts of a Wide Area Release of Anthrax}

KS Judd

JL Olson

SL Stein

AM Lesperance

May 29, 2009

Prepared for the U.S. Department of Defense, Defense Threat Reduction Agency under Contract IACRO\#B0844731 and the U.S. Department of Homeland Security.

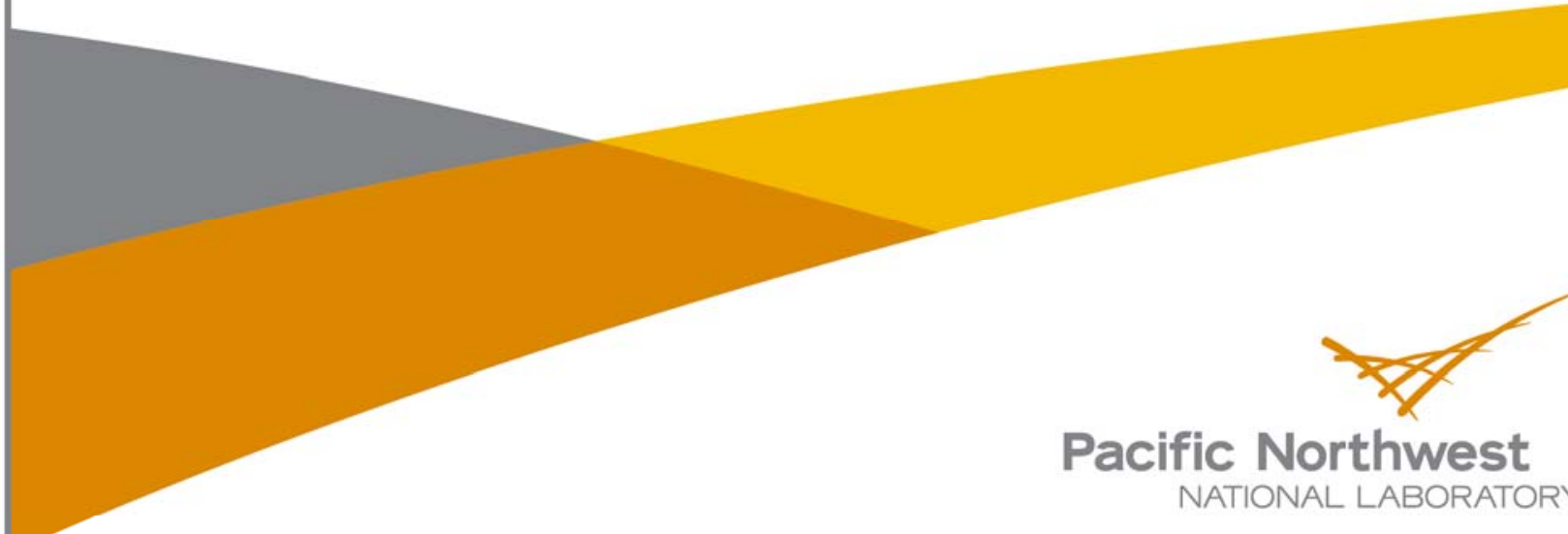

Supported by the Northwest Regional Technology Center for Homeland Security 


\title{
DISCLAIMER
}

This report was prepared as an account of work sponsored by an agency of the United States Government. Neither the United States Government nor any agency thereof, nor Battelle Memorial Institute, nor any of their employees, makes any warranty, express or implied, or assumes any legal liability or responsibility for the accuracy, completeness, or usefulness of any information, apparatus, product, or process disclosed, or represents that its use would not infringe privately owned rights. Reference herein to any specific commercial product, process, or service by trade name, trademark, manufacturer, or otherwise does not necessarily constitute or imply its endorsement, recommendation, or favoring by the United States Government or any agency thereof, or Battelle Memorial Institute. The views and opinions of authors expressed herein do not necessarily state or reflect those of the United States Government or any agency thereof.

\author{
PACIFIC NORTHWEST NATIONAL LABORATORY \\ operated by \\ BATTELLE \\ for the \\ UNITED STATES DEPARTMENT OF ENERGY \\ under Contract DE-AC05-76RL01830
}

Printed in the United States of America
Available to DOE and DOE contractors from the Office of Scientific and Technical Information,
P.O. Box 62, Oak Ridge, TN 37831-0062;
ph: (865) 576-8401
fax: $(865)$ 576-5728
email: reports@adonis.osti.gov

\begin{abstract}
Available to the public from the National Technical Information Service, U.S. Department of Commerce, 5285 Port Royal Rd., Springfield, VA 22161 ph: (800) 553-6847 fax: $(703) 605-6900$ email: orders@ntis.fedworld.gov online ordering: http://www.ntis.gov/ordering.htm
\end{abstract}

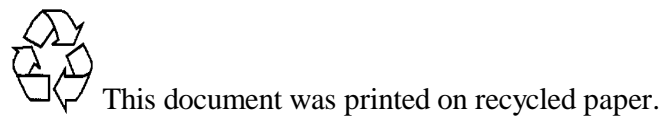




\section{Table of Contents}

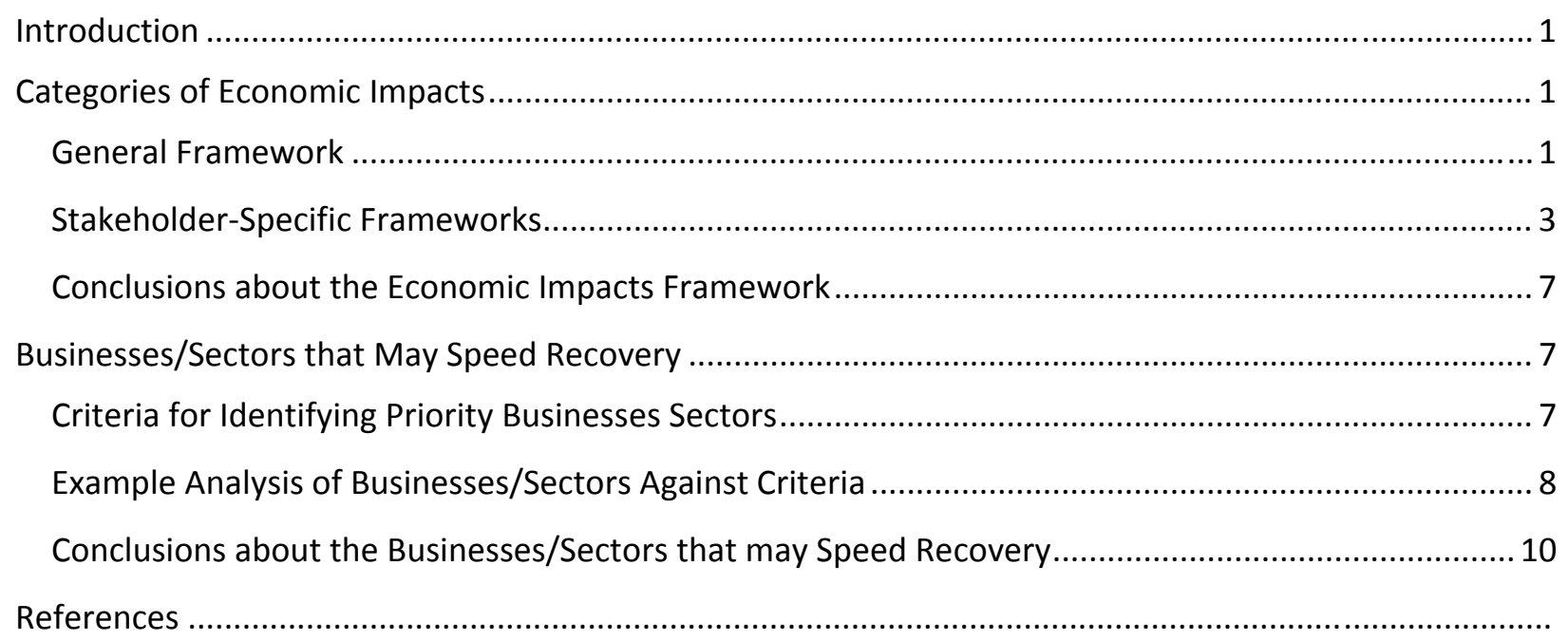

\section{Figures and Tables}

Figure 1. General framework for analysis of economic impacts. ....................................................... 2

Figure 2.Framework for analyzing government costs from an anthrax incident. .................................... 4

Figure 3. Framework for analyzing business costs from an anthrax incident.......................................... 5

Figure 4. Framework for analyzing building owner costs from an anthrax incident. ..............................6 6

Table 1. Evaluation of select industry sectors against criteria that may speed economic recovery............9 


\section{Introduction}

The objective of this task is to further explore the economic impacts that might result from a widearea release of anthrax. The intent is not to provide a quantitative analysis of such a disaster, but to:

1. Define the general categories of economic impacts that the region should be concerned about; and,

2. Explore what types of private sector businesses or industries, if any, may have the greatest impact on speeding the economic recovery of the region.

This analysis was conducted through a review of literature on regional economic development, regional resiliency, and the economic impacts of major disasters, including Hurricane Katrina, the 9/11 attacks, and other hypothetical analyses.

\section{Categories of Economic Impacts}

This information is intended to help government officials, private businesses, and building owners and operators think about the range of potential economic costs from a wide-area release of anthrax and how those costs might vary by stakeholder. This may be used to support discussions about assumptions and uncertainties regarding stakeholder responsibility for different costs.

\section{General Framework}

A general framework was developed to define broad cost categories that would be relevant to three stakeholder groups in a catastrophic anthrax incident: government, private business, building owners and operators. Exact costs will depend on variables specific to the site of the incident and variables specific to the attack (Figure 1). Costs would also be driven by the timeline of the incident and for purposes of this analysis include costs incurred during incident response, restoration and recovery phases.

General cost categories include:

- Loss of Life includes costs associated with compensation for lost earnings, which may be paid by insurance policies, the government (e.g. the Victim's Compensation Fund established after 9/11), businesses, or charities; or the costs may be absorbed by individual families. There may also be costs associated with lost productivity from loss of life as organizations are forced to operate without essential staff. A potential cost could come in the form of liability for loss of life if building owners were thought to have provided inadequate protection.

- Healthcare refers to costs associated with diagnosis and treatment of the sick or injured and responding to the worried well. There may also be costs related to the overburdened infrastructure from mass casualties, infected individuals, the worried well, and volunteers showing up at healthcare facilities (e.g. setting up temporary care sites, heavy wear on facilities and equipment). These costs would fall heavily on the government, who would 
provide the surge medical care to the area, release the national stockpile, and likely provide medications for free, but could also impact hospital owners and the insurance industry.

- Damage and Loss of Property refers to costs associated with damaged property and lost assets that require replacement, as opposed to decontamination and decommissioning (separate category). These would accrue to all three stakeholders as owners of facilities. Other costs may include insurance losses on property. For the federal government, there may also be costs associated with allocation of grant funding to state and local agencies and other critical responders under the Stafford Act.

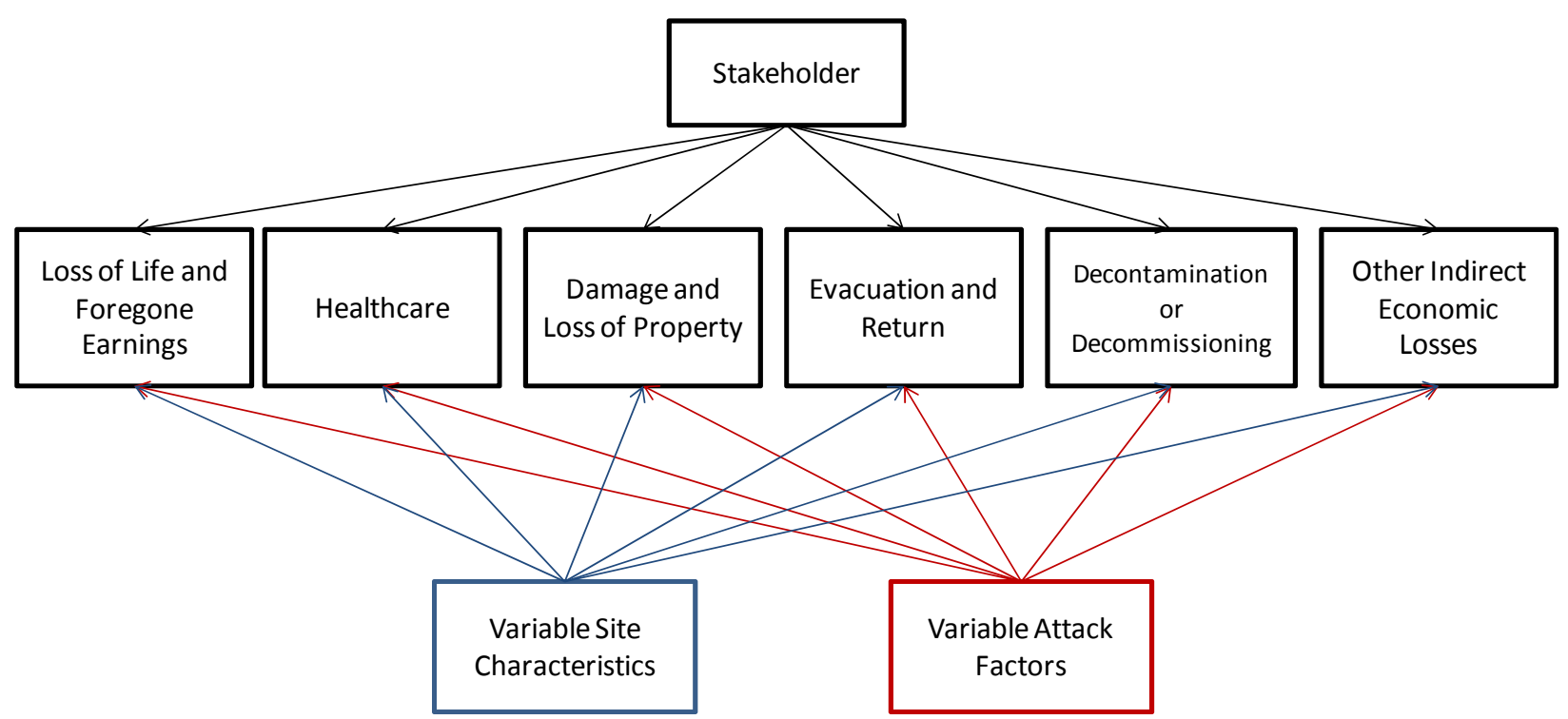

Figure 1. General framework for analysis of economic impacts.

- Evacuation and Return costs are those associated with physically moving citizens and businesses away from the contaminated and possibly surrounding area, either voluntarily or through or planned evacuation. There will be costs for government to keep people out of unsafe areas as well. And when it is time to repopulate the evacuated areas, there may be costs to support the return to homes and businesses. Finally, there may be costs associated with temporarily relocating people and businesses and incentivizing them return to their homes or buildings.

- Decontamination or Decommissioning refers to the broad set of costs associated with cleaning up buildings, homes, and critical infrastructure that might have been contaminated in the attack. It may also be determined that an area/building is not a good candidate for decontamination due to economic, legal, or other factors, and may be decommissioned instead. Examples of decontamination costs include sampling and testing, remediation labor, supplies and equipment costs, and waste disposal. There could also be costs resulting from liability for exposure during cleanup or for inadequate cleanup.

- Other Indirect Economic Losses captures other means through which value could be lost to government and the private sector as a result of the disruption to the economy. The loss of income will have a major impact on all stakeholder groups, and could ultimately cause defaulting on loans or tightened access to credit. The government's main source of income is tax revenue, which will be affected when its residential and commercial population 
evacuates or is impaired. Businesses earn revenue from commerce; beyond the direct loss of commerce from businesses forced to close or relocate, factors such as loss of consumer confidence will have a negative effect on businesses throughout the regional economy. Building owners' primary source of income is rent from leasing its facilities to businesses or residents. Dislocation of businesses and residents would severely impact building-owner income. Finally, rising civil unrest as a result of increasing social stratification, a growth in potential hate crimes and discrimination may result in other costs to property owners and society as a whole.

The general categories of economic costs were derived and adapted from existing models for characterizing the costs of a catastrophic loss. (See References.) Some of the existing models, such as those developed by Adam Rose ${ }^{1}$ and Stephane Hallegatte's ${ }^{2}$ break the analysis down into great detail, at a level that is more relevant for post-facto analysis than a general analysis of a masscasualty event. Other analyses, such as Whicker et al.'s Adaptive Management Paradigm ${ }^{3}$, are more general, providing a useful model for assessing the management of an emergency, but do not adequately support an assessment of associated costs. Finally, many models focus on short-term immediate effects such as property devaluation and the cost of evacuation, but do not address preservation of the social system, which is vital to the recovery of an urban area. An effort was made to incorporate an appropriate level of cost detail into the current framework, as well as types of indirect costs, such as social order, that can have a real impact but are often left out of models.

\section{Stakeholder-Specific Frameworks}

The following diagrams examine specific types of costs that are likely to result for each of the three broad stakeholder groups described above. Figure 2 illustrates costs that would likely affect government, Figure 3 characterizes costs that might affect businesses, and Figure 4 relates specifically to building owners. While there is overlap in the cost categories across government, businesses, and building owners, the depth and impact of these costs will likely vary significantly by stakeholder due to their different responsibilities, liabilities, and revenue sources. In many cases there are gray areas of responsibility and liability. For example, all three stakeholders may absorb costs for facility cleanup, waste disposal, or building decommissioning, but it is not clear to all to what extent each sector would be responsible for those costs.

\footnotetext{
${ }^{1}$ Rose, Adam. "A Framework for Analyzing the Total Economic Impacts of Terrorist Attacks and Natural Disasters," Journal of Homeland Security and Emergency Management: Volume 6, Issue 1, 2009

${ }^{2}$ Hallegatte, Stephane. "An Adaptive Regional Input-Output Model and its Application to the Assessment of the Economic Cost of Katrina," Risk Analysis: Volume 28, Number 3, 2008

${ }^{3}$ Whicker, Jeffrey J., David R. Janecky, and Ted B. Doerr, “Adaptive Management: A Paradigm for Remediation of Public Facilities Following a Terrorist Attack." Risk Analysis, Volume 28, Number 5, 2008
} 




Figure 2.Framework for analyzing government costs from an anthrax incident. 


\begin{tabular}{|c|c|c|c|c|c|}
\hline $\begin{array}{c}\text { Life Loss of Life } \\
\text { and Foregone } \\
\text { Earnings }\end{array}$ & Healthcare & $\begin{array}{c}\text { Damage and } \\
\text { Loss of Property }\end{array}$ & $\begin{array}{c}\text { Evacuation and } \\
\text { Return }\end{array}$ & $\begin{array}{l}\text { Decontamination } \\
\text { or } \\
\text { Decommissioning }\end{array}$ & $\begin{array}{l}\text { Other Indirect } \\
\text { Economic Losses }\end{array}$ \\
\hline $\begin{array}{l}\text {-Insurance } \\
\text { payouts for loss of } \\
\text { life } \\
\text {-Direct } \\
\text { compensation to } \\
\text { families of lost } \\
\text { private sector } \\
\text { employees? } \\
\text {-Productivity loss } \\
\text { from lost private } \\
\text { sector employees }\end{array}$ & $\begin{array}{l}\text {-Diagnosis of sick } \\
\text { and worried well } \\
\text {-Treatment } \\
\text {-Overburdened } \\
\text { private healthcare } \\
\text { infrastructure }\end{array}$ & $\begin{array}{l}\text {-Replacement of } \\
\text { lost private assets } \\
\text {-Productivity loss } \\
\text { from loss assets }\end{array}$ & $\begin{array}{l}\text {-Temporary } \\
\text { relocation of } \\
\text { operations } \\
\text {-Temporary } \\
\text { relocation of } \\
\text { employees? }\end{array}$ & $\begin{array}{l}\text {-Facility cleanup } \\
\text {-Sampling and } \\
\text { testing pre- and } \\
\text { post cleanup } \\
\text {-Waste disposal } \\
\text { - Liability for } \\
\text { cleanup exposure? } \\
\text {-Liability for } \\
\text { inadequate } \\
\text { cleanup? }\end{array}$ & $\begin{array}{l}\text {-Decreased access to } \\
\text { credit / defaults on } \\
\text { loans } \\
\text {-Productivity loss from } \\
\text { employee absenteeism, } \\
\text { reduced work hours } \\
\text {-Productivity loss from } \\
\text { supply chain disruption } \\
\text {-Lost sales from } \\
\text { perception of } \\
\text { contamination, product } \\
\text { substitution, consumer } \\
\text { displacement } \\
\text {-Overburdened private } \\
\text { infrastructure (e.g. cell } \\
\text { towers) } \\
\text {-Insurance rates } \\
\text { increase? } \\
\text {-Cost of civil unrest }\end{array}$ \\
\hline
\end{tabular}

Figure 3. Framework for analyzing business costs from an anthrax incident. 


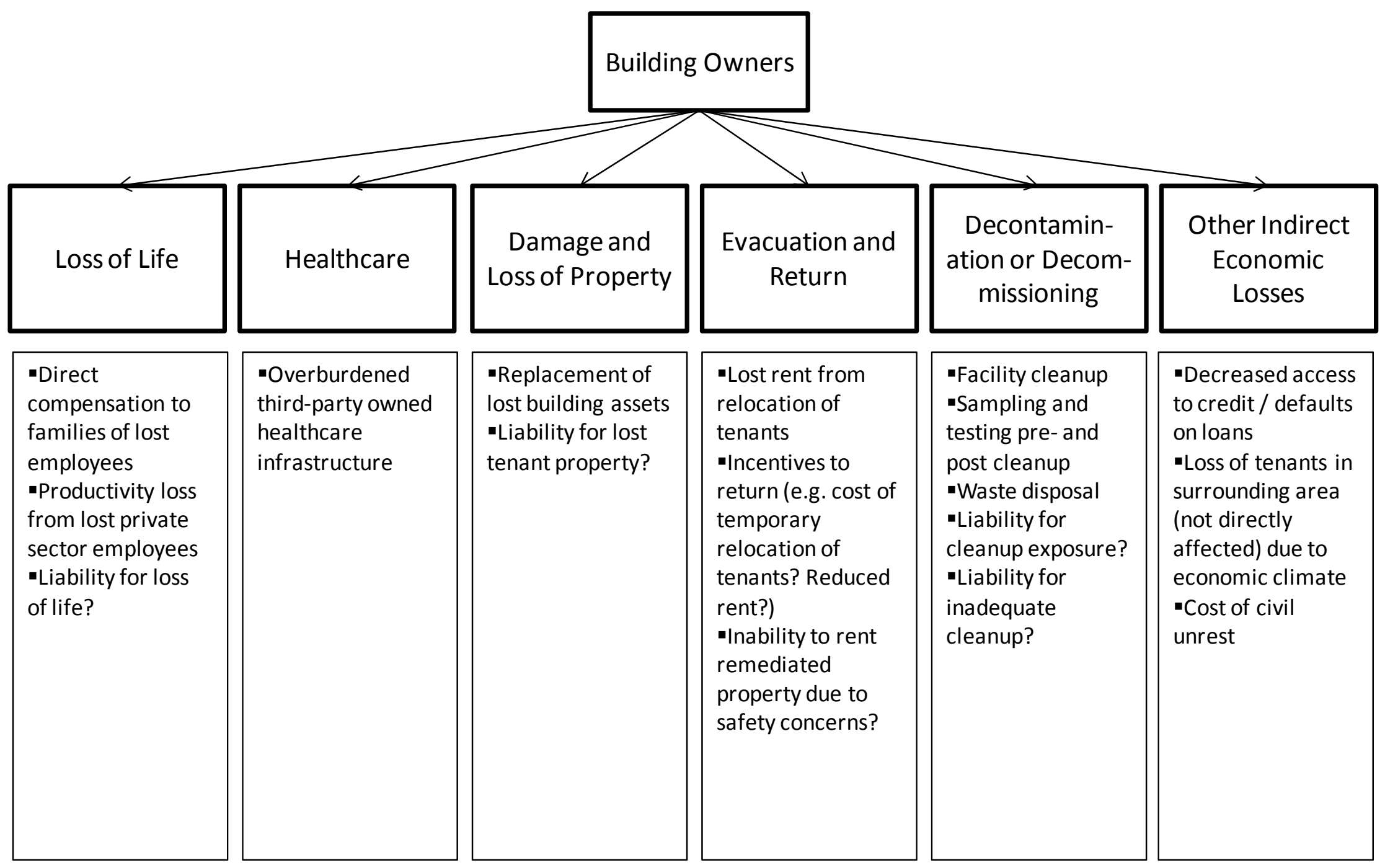

Figure 4. Framework for analyzing building owner costs from an anthrax incident. 


\section{Conclusions about the Economic Impacts Framework}

This analysis attempts to provide a flexible, qualitative framework for examining potential costs associated with a wide-area release of anthrax, as it may impact three different stakeholder groups: government, businesses, and building-owners. It allows for variable factors like the nature and extent of the attack to remain outside the cost estimation for simplicity. While it could be further developed with quantitative information to arrive at cost projections to each sector or to individual organizations, the intent of the framework is provide a point of departure for discussing likely categories of costs and assumptions about accountability for those costs. When discussing the financial implications and liabilities of such an event with stakeholders from the private and public sectors, it has been clear that there are various and divergent expectations and assumptions about who would pay for what. This framework may be used to vet and clarify such assumptions among public and private stakeholders.

\section{Businesses/Sectors that May Speed Recovery}

This part of the analysis explores whether particular businesses or sectors might be well-positioned to speed economic recovery if its restoration after a wide-area release of anthrax were prioritized. Many of the existing models for physical restoration of an area assume that government property and critical infrastructure should be decontaminated first. While government plays a critical role, it is not a revenue generator for the region. Businesses that can help reestablish the tax revenue stream into local government, while providing other important benefits, may warrant prioritization of restoration over government buildings, if the goal is to speed economic recovery.

\section{Criteria for Identifying Priority Businesses Sectors}

To help determine what types of businesses might be key contributors to the region's economic recovery, we reviewed assessments of regional economic development for the greater Seattle area and other cities and defined additional criteria thought to be potentially good indicators of a business's impact on the regional economy following a disaster. Regional economic development groups use criteria such as number of jobs and multiplier effects to define priority industry clusters in the region. Other factors that may be important relate to the nature and substitutability of the product or service offered by the business.

Potential criteria to support an analysis of priority businesses/sectors include:

- Number of direct employees/jobs created

- Sector job multiplier effect (i.e. the impact of jobs created in ancillary sectors)

- Impact of business/sector on city tax base

- Competitiveness of the sector in Seattle relative to other cities (This can be measured by Employment Concentration Ratio (ECR), which is the sector's share of employment in the region relative to the national average. ECR indicates strong market position or specialization. More than likely the industry is exporting goods or services out of the region; therefore this could be important to minimize national impacts depending on the reach of the sector.) 
- Location dependence of service/product provided (e.g. does the product/service need to be made available in downtown Seattle or you could it be made available just as easily in a neighboring city?)

- Whether the business provides a vital product/service (e.g. food) versus a luxury item (e.g. designer handbags)

\section{Example Analysis of Businesses/Sectors Against Criteria}

Data on how some sectors perform against some of these criteria is available in a number of regional industry sector studies supported by the City of Seattle Office of Economic Development ${ }^{4}$ and in economic analysis of Central Puget Sound sponsored by the Puget Sound Regional Council. ${ }^{5}$ Other data was estimated based on the authors' independent research and assessment.

It should be noted that city and county economic impact studies do not examine all sectors that operate in the region, but a set of geographically concentrated industry "clusters" that were determined important to driving economic growth of the region. This cluster theory may have some utility to the assessment of strategies to help drive economic development after an event such as a wide area release of anthrax. The industry clusters have the characteristic that they can or do export goods and services outside of the region. While sectors like education, government, local business and personal services are important and are some of the largest employers in a region, their focus is usually centered on serving the local population and economy. So they are considered more a product of the local economic growth than a cause of it. In the event of a wide-area release of anthrax, these types of foundation sectors will ultimately be important to regional economic recovery; however businesses in the region's critical industry clusters may be better-positioned to facilitate and speed economic recovery. The table below summarizes performance of the major regional industry clusters against the criteria defined above.

\footnotetext{
${ }^{4}$ Industry economic impact studies available at: http://www.seattle.gov/economicdevelopment/maj ind sectors.htm.

5 "Economic Analysis of the Central Puget Sound Region: Volume II of the Regional Economic Strategy." September 27, 2005. Prepared for Puget Sound Regional Council by Economic Competitiveness Group, Inc. and Global Insight, Inc. Available at: http://www.prosperitypartnership.org/pubs.htm].
} 
Table 1. Evaluation of select industry sectors against criteria that may speed economic recovery.

\begin{tabular}{|c|c|c|c|c|c|c|}
\hline Sector & $\begin{array}{l}\text { \# of jobs in } \\
\text { city/county }\end{array}$ & $\begin{array}{l}\text { Multiplier } \\
\text { effect }\end{array}$ & $\begin{array}{l}\text { Contribution to } \\
\text { City tax base } \\
\text { (retail and } \mathrm{B} \& 0 \text { ) }\end{array}$ & ECR* (King County) & $\begin{array}{l}\text { Location } \\
\text { dependence }\end{array}$ & $\begin{array}{l}\text { Vital vs. } \\
\text { luxury }\end{array}$ \\
\hline Basic Industries & 121,700 & $\mathrm{n} / \mathrm{a}$ & $\$ 84.7 \mathrm{M}$ & & & \\
\hline *aerospace & (2001 Seattle) & & & 9.93 (aerospace) & High & Most are \\
\hline *construction & & & & & Low & vital \\
\hline * food/beverage & & & & 2.29 (specialty food) & High & \\
\hline * industrial machinery \& fab metal & & & & & Low & \\
\hline${ }^{*}$ stone/clay/glass/concrete products & & & & 2.3 (water transport) & Low & \\
\hline *transportation/distribution & & & & 2.8 (air transport) & High & \\
\hline *seafood processing & & & & 4.9 (logist/intl trade) & High & \\
\hline *office/home furnishings & & & & & Low & \\
\hline *printing/publishing & & & & & Low & \\
\hline Maritime & $\begin{array}{l}22,129 \\
(2002 \text { Seattle })\end{array}$ & 2.05 & & 1.74 (boat building) & High & Vital \\
\hline Life Sciences & $\begin{array}{l}\mathbf{1 9 , 3 6 0} \\
(2002 \text { Seattle })\end{array}$ & 2.23 & $\begin{array}{l}\$ 24.6 \mathrm{M} \\
\text { (statewide) }\end{array}$ & 1.65 & Low & Vital \\
\hline $\begin{array}{l}\text { Information and Communications } \\
\text { Technology }\end{array}$ & $\begin{array}{l}\mathbf{1 8 , 2 5 0} \\
(2002 \text { Seattle })\end{array}$ & & $\$ 14.8 \mathrm{M}$ & 1.96 (IT) & Low & Depends \\
\hline Healthcare & $\begin{array}{l}\mathbf{7 4 , 6 0 0} \\
\text { (2002 Seattle) }\end{array}$ & 1.56 & $\$ 29.6 \mathrm{M}$ & 1.18 (long-term care) & High & Vital \\
\hline
\end{tabular}

${ }^{*}$ An employment concentration ratio (ECR) greater than 1 implies that the industry produces more goods and services than required to meet the demands of the local market. In other words, the cluster is more concentrated in the region than it is at the national level. 
Basic industries jobs generally include the broad sectors of: 1) construction, 2)manufacturing, and 3 ) wholesale trade, communications and utilities. In the City of Seattle economic analysis they there further broken into the nine sub-clusters identified in the table.

The maritime sector includes fishing, shipbuilding, water transportation, seafood processing, cruise ship business, boat dealers/suppliers, as well as major support industries including cold storage, marinas, marine terminals, fuel, and others. ${ }^{6}$ There is some overlap between data on this sector and the manufacturing sector in the City's economic impact studies.

The assessment of the biotechnology sector included biotechnology (defined as the application of biological knowledge and techniques pertaining to molecular, cellular, and genetic processes to develop products and services) and medical devices.

The information and communication technologies industry in Seattle includes software developers and engineers, programmers, analysts, administrators, and graphic designers.

Finally, Seattle's healthcare industry includes healthcare professionals, hospitals, healthcare products, healthcare services, and research and training organizations. One in five jobs in Seattle is tied to this healthcare industry cluster.

In a real anthrax incident, the criteria in the table would ideally be applied to a set of specific businesses that had been operating in the affected area. Data on employment numbers and tax revenue should be available for a business of interest. Multiplier effects of the business in question may be calculated using the industry ratio.

\section{Conclusions about the Businesses/Sectors that may Speed Recovery}

This analysis is intended to demonstrate the value of defining a set of criteria for restoration prioritization with the goal of facilitating and speeding regional economic recovery, and to exemplify the type of analysis that could support an assessment of priority businesses for restoration. The specific sectors analyzed above should not be viewed as a recommendation or endorsement by PNNL, but are used to illustrate an economic development driven approach to recovery. Businesses in foundation or support sectors will also be important to economic recovery of the region. However, businesses that support a lot of jobs, directly and indirectly, contribute significantly to the local tax base, have a competitive advantage in the region, and provide products and/or services that are vital and need to be accessible at a specific location, could provide a strategic advantage in terms of their contribution to economic recovery.

\footnotetext{
${ }^{6}$ Sommer, P. and D. Andreoli. Seattle's Maritime Cluster: Characteristics, Trends and Policy Issues. April 28, 2004. Prepared for the Seattle Office of Economic Development. Available at: http://www.seattle.gov/economicdevelopment/industry maritime.htm
} 


\section{References}

Robert A. Baade, Robert Baumann and Victor Matheson," Estimating the Economic Impact of Natural and Social Disasters, with and Application to Hurricane Katrina," Urban Studies: Volume 44, Number 11, October 2007: 2061-2076

Jason Bram, James Orr, and Carol Rapaport, "Measuring the Effects of the September 11 Attack on New York City," FRBYN Economic Policy Review: November 2002: 5-20

Dorothy A. Canter, et al, "Remediation of Bacillus anthracis Contamination in the U.S. Department of Justice Mail Facility," Biosecurity and Bioterrorism: Biodefense Strategy, Practice and Science: Volume 3, Number 2, 2005: 119-127

C.E. Colten, R.W. Kates and S.B. Laska, "Community Resilience: Lessons from New Orleans and Hurricane Katrina," CARRI Research Report 3: September 2008, http://www.resilientus.org/publications/reports.html

GAO, “Capital Hill Anthrax Incident: EPA's Cleanup Was Successful; Opportunities Exist to Enhance Contract Oversight," GAO: June 2003 - GAO-03-686

Stephane Hallegatte, "An Adaptive Regional Input-Output Model and its Application to the Assessment of the Economic Cost of Katrina," Risk Analysis: Volume 28, Number 3, 2008: 779-799

Betty Hearn Morrow, “Community Resilience: A Social Justice Perspective," CARRI Research Report 4: September 2008, http://www.resilientus.org/publications/reports.html

Joshua A. Mott, et al, "Call-Tracking Data and the Public Health Response to Bioterrorism-Related Anthrax," Emerging Infectious Diseases: Volume 8, Number 10, October 2002: 1088-1092

Adam Z. Rose, "A Framework for Analyzing the Total Economic Impacts of Terrorist Attacks and Natural Disasters," Journal of Homeland Security and Emergency Management: Volume 6, Issue 1, 2009: Article 9 